Raymart O. Basco, Ph.D.

Batangas State University ARASOF-Nasugbu

Batangas, Philippines
Original scientific paper

UDC: 37.025

DOI: $10.5937 /$ IstrPed2002313B

\title{
EFFECTIVENESS OF SCIENCE INFOGRAPHICS IN IMPROVING ACADEMIC PERFORMANCE AMONG SIXTH GRADE PUPILS OF ONE LABORATORY SCHOOL IN THE PHILIPPINES
}

\begin{abstract}
This study determined the effectiveness of science infographics in improving academic performance among sixth-grade pupils of Batangas State University ARASOF- Nasugbu Laboratory School. Based on the results of the multiple pre-test and post-tests of 26 pupils, the findings elucidated that the respondents performed significantly better in their post-test. The results implied that infographics were significant in terms of improving academic performance in Science among learners. Additionally, findings revealed that critical thinking skills, recall information, understanding complex information, and organizing information into logical groups may be improved through infographics. Further, infographics were found to improve learners'ability to communicate to others what they have learned, improve presentation skills, acquire teamwork, increase motivation to learn, improve the ability to give and receive feedback, and gain self-confidence to learn and succeed. An infographics paradigm was developed based on the study results to understand further the infographics'potentials in the teaching and learning process.
\end{abstract}

Keywords: Science infographics, improving academic performance, laboratory school, sixth grade pupils.

\section{Introduction}

Science education is focused on developing students' scientific literacy that will equip them to be rational and participative citizens who can make decisions and judgments concerning the utilization of scientific knowledge that may have health, environmental, or social impacts (Department of Education, 2016). However, as it was highlighted in the assessment results conducted by the Programme for International Student Assessment (Department of Education, 2019.), Filipino learners garnered an average of 357 points in scientific literacy, which was comparatively lower than the 489 points which are the average for the Organisation for Economic Co-operation and Development (OECD).

Declining science performance is reflected in the National Achievement Test mean percentage scores in Science, 66.11, 30.94, and 29.05 for S. Y. 2011-2012, 2016-2017, and 2017-2018, respectively. These were quite far below the set standard of the DepEd, which was $75 \%$. With this existing problem, it is essential to exert maximum efforts to address poor science performance among Filipino learners. One of the innovative ways to improve academic performance is to introduce strategies such as infographics in teaching science concepts. 
Several researchers explored the instructional relevance of infographics in different subjects and areas (Ozdamli, Kocakoyun, Sahin, \& Akdag, 2016; Alrwele, 2017; Fowler, 2015; Damyanov \& Tsankov, 2018; and Noh, Fauzi, \& Jing, 2017).

Infographics are composed of visual representations and brief explanatory texts that are put together to convey messages that are captivating and simple to understand. The influence of infographics are brought by the diverse representations that may be used, including bar graphs, pie charts, histograms, zoom boxes, tree diagrams, line charts, icons, and even photographs (Parkinson, 2016; Rezaei \& Sayadian, 2015; Wertz \& Saine, 2014). Infographics are used as visual tools to communicate ideas and describe data to the broad community rather than the scientific community (Polman \& Gebre, 2015).

Infographics are comprised three main components: content elements (texts, facts, references, statistics, etc.), visual elements (graphics, maps, colors, icons, signs, etc.), and knowledge (messages, conclusions, etc.).They can effectively facilitate organizations or individuals to deliver the information to the specified audience concisely (Siricharoen \& Siricharoen, 2015; Noh, Fauzi, \& Jing, 2017).Further, as infographicsintegrate arts into the general earnest dimension of mathematical information, they are viewed as an exceptionally functional tool to convey information that can be utilized to transfer complex or high amount of data (Davidson, 2014; Ozdamli, Kocakoyun, Sahin, \& Akdag, 2016).

Similarly, Naparin and Saad (2017) is on the opinion that infographics are distinctive formation of mental visual images. Additionally, as both learners and educators associate creative visualization with meaningful approach to convey direct information, they likewise utilize it as a learning tool. Infographics, when presented with quality can effectively transfer knowledge about a specific content than pure text.

Ozdamli, Kocakoyun, Sahin, and Akdag (2016) determined students' views about infographics. The study revealed that when compared to traditional course visuals, infographics were practical visual tools. Further, the respondents perceived that it was more easy to understand and more satisfactory when the subject was taught using infographics. Moreover, infographics were found to be more effective in terms of concept recall and retention. This study likewise revealed in other subjects or courses, educators and learners may use infographics. Findings claimed that through the strategy, the information could be transmitted in the increasingly widespread use. Consequently, the usual form of lectures might be be transformed to become simple, comprehensible courses when infographics were incorporated.

Alrwele (2017) investigated the effectiveness of infographics on students' academic achievement and explored students' perceptions of the impact of infographics. The results revealed that the experimental group significantly performed better than the control group. Ninety percent (90\%) in the experimental group claimed that infographics positively impacted their intellectual, life skills, and affective development. Additionally, the study indicated that infographics could have substantial education possibilities to improve life skills, intellectual and affective dimensions among learners. Similarly, infographics were noted to be useful for enhancing learners' achievement in learning lessons/courses. The study results offered solutions among educators who teach abstract or multifaceted concepts that were complex to explain using orally presented material and written text because infographics can be alternative instructional tools. 
In his study, Fowler (2015) involved learners in designing infographics for their lessons in Science. The results found outthat infographics addressed misconceptions in Science; improved higher-order thinking skills which include critical thinking, analysis synthesis, and advanced creative presentations.

It can further be supported by the study conducted by Damyanov and Tsankov (2018). They described infographics as a modeling method that created conditions for advancing various cognitive skills, encompassing explanation, interpretation, evaluation, analysis, and conclusion.

Shively and Maine (2012) found that infographics were ideal $21^{\text {st }}$-century tools supporting and scaffolding learning among educators and learners.

Noh, Fauzi, and Jing (2017) examined infographics as a tool to facilitate the educative process. The findings suggested that instructors' assignments without proper guidelines and too many slides in the presentation, and too wordy information presented by instructors were the main learning problems encountered by respondents. The researchers also discovered that all infographics features, such as symbols and images, attractive colors, sound design, short diagrams or charts, and texts encouraged learners to understand effectively information and concepts delivered through them. Further, infographics to facilitate learning were valued due to infographics' appropriateness to deliver concise and coherent information, increase productivity and creativity, and develop focus and understanding in the learning process. Thus, as one of the tools to address learners'visual literacy problems, infographics should be promoted and explored.

Based on the aforementioned literature, it can be stated that there is a significant usefulness and practicality of infographics as instructional tools. However, Filipino learners continuously manifest their significantly low science performance inconsistent with these infographics' positive effects as instructional tools. Thus, this study was undertaken to provide lighton the existing gap on the effectiveness of infographics in improving Science academic performance in the context of the Philippines.

\subsection{Objectives of the Study}

This study aimed to examine the effectiveness of infographics in improving Science academic performance among sixth-grade pupils of Batangas State University ARASOF NasugbuLaboratory School.

Further, it sought answers to the following specific questions:

1. What is the performance of the respondents in the pre-test and post-test?

2. How significant is the difference between the pre-test and post-test scores of the respondents?

3. What are the impacts of infographics as perceived by the respondents in terms of:

3.1 intellectual,

3.2 life skills, and

3.3 affective development?

4. Is there a significant relationship between the respondents' performance and their perception of the impacts of infographics?

5. What infographics paradigm may be developed base on the results of the study? 


\section{Method}

\subsection{Research Design}

To determine the effectiveness of infographics in improving academic performance among grade six pupils of Batangas State University ARASOF Nasugbu- Laboratory School AY 20202021, a quasi-experiment design was utilized in one treatment group with four observations before and after the treatment (Shadish, Cook, \& Campbell, 2002). Further, a descriptivesurvey method was employed to gauge the impacts of infographics as perceived by the respondents.

\subsection{Respondents}

The respondents of the study were 25 Grade 6- pupils of Batangas State University ARASOFNasugbu Laboratory School for the school year 2020- 2021. Purposive total sampling was used to select the respondents. The pupil-participants were taught using infographics.

\subsection{Data Gathering Procedure}

The researcher consulted the principal regarding the present action research. Upon the principal's given approval, assent and consent form were secured from the respondents and their parents/ guardians before the researcher conducted the pre-test for the week's lesson. After every lesson, a post-test was given to assess their mathematical performance. Likewise, a survey-questionnaire was adopted from the study of Arlwele (2017). The researcher provided the questionnaire to the respondents to gauge their perception of the impacts of infographics.

\subsection{Data Analysis}

The results of the study were interpreted and analyzed using Statistical Package for Social Sciences (SPSS). Mean, weighted mean, standard deviation, t-test, and Pearson Product Moment Correlation Coefficient- $r$ were utilized to statistically examine the study results.

\section{Findings and Discussion}

\subsection{Performance of the Respondents in the Pretest and Post-test}

The results of the pre-test and post-test of the respondents are revealed in Table 1.

Table 1: Respondents'Pre-test and Post-test Performance

\begin{tabular}{|c|c|c|c|}
\hline & MEAN & STANDARD DEVIATION & MEAN DIFFERENCE \\
\hline Post Test 1 & 8.32 & 1.22 & \multirow{2}{*}{3.56} \\
\hline Pre Test 1 & 4.76 & 1.09 & \multirow{2}{*}{4.44} \\
\hline Post Test 2 & 8.44 & 1.19 & \multirow{2}{*}{3.88} \\
\hline Pre Test 2 & 4.00 & 1.38 & \multirow{2}{*}{3.28} \\
\hline Post Test 3 & 8.56 & 1.08 & 1.49 \\
\hline Pre Test 3 & 4.68 & 1.06 & 0.92 \\
\hline Post Test 4 & 8.72 & & \\
\hline Pre Test 4 & 5.44 & &
\end{tabular}


The results of the multiple pre-tests and post-test results revealed in Table 1 presents that mean differences of $3.56,4.44,3.88$, and 3.28, respectively. This substantiated the effectiveness of infographics in teaching Science. It further validates that infographics can be utilized as a learning tool in education for both learners and educators (Naparin \& Saad, 2017).

Additionally, infographics are practical tools to increase concept retention (Ozdamli, Kocakoyun, Sahin, \& Akdag, 2016). The results confirm that infographics deliver concise and coherent information that increases productivity and creativity and develops focus and understanding in the learning process (Noh, Fauzi, \& Jing, 2017).

\subsection{Differences in the Respondents Pre-test and Post-test}

The results of the pre-test and post-test of the respondents are shown in Table 2.

Table 2: Differences in the Respondents'Pre-test and Post-test Performance

\begin{tabular}{|c|c|c|c|c|}
\hline & t-value & t-critical value & df & Sig.2 (tailed) \\
\hline Pre-Post Test 1 & 21.692 & 2.064 & 24 & .000 \\
\hline Pre-Post Test 2 & 18.086 & 2.064 & 24 & .000 \\
\hline Pre-Post Test 3 & 13.356 & 2.064 & 24 & .000 \\
\hline Pre-Post Test 4 & 16.056 & 2.064 & 24 & .000 \\
\hline
\end{tabular}

From the respondents' pre-test and post-test results, computed t-values were 21.692, 18.086, 13.356 , and 16.056, which areall greater than the t-critical values of 2.064 , significant at 0.05 . It led to the rejection of the null hypothesis; hence, there was a considerable difference in the respondents' pre-test and post-test results. With infographics, academic performance among learners may be improved as it integrates arts into the general earnest dimension of numerical information (Davidson, 2014).

Also, the study can be supported by the findings that all features of infographics, such as the use of symbols and images, attractive colors, sound design, short diagram or chart, and texts encouraged learners to understand effectively information and concepts delivered through them (Noh, Fauzi, \& Jing, 2017).

The findings confirm that infographics were ideal 21st-century tools that supportand scaffold learning among educators and learners (Shively \& Maine, 2012). Thus, it can be claimed that infographics, when utilized in teaching Science, can be an effective strategy to enhance pupils' academic performance.

\subsection{Perception of the Respondents on the Impacts of Infographics in Terms of Intellectual Development}

Table 3: Respondents'Perception of the Impacts of Infographics in Terms of Intellectual Development

\begin{tabular}{|c|c|c|c|}
\hline \multicolumn{1}{|c|}{ Intellectual } & WM & SD & $\begin{array}{c}\text { Verbal } \\
\text { Interpretation }\end{array}$ \\
\hline $\begin{array}{l}\text { 1. I believe that infographics help me easily understand complex } \\
\text { information. }\end{array}$ & 3.52 & 0.71 & Strongly Agree \\
\hline $\begin{array}{l}\text { 2. I believe that infographics help me easily understand complex } \\
\text { information. }\end{array}$ & 3.64 & 0.49 & Strongly Agree \\
\hline $\begin{array}{l}\text { 3. I think that infographics enable me to determine keywords and } \\
\text { concepts in a text. }\end{array}$ & 3.16 & 0.85 & Agree \\
\hline
\end{tabular}




\begin{tabular}{|c|c|c|c|}
\hline 4. I believe that infographics help me filter out irrelevant data. & 3.08 & 0.64 & Agree \\
\hline $\begin{array}{l}\text { 5. I feel that infographics help me organize information into logical } \\
\text { groups. }\end{array}$ & 3.60 & 0.50 & Strongly Agree \\
\hline $\begin{array}{l}\text { 6. I think that infographics help me to understand hidden } \\
\text { relationships. }\end{array}$ & 3.16 & 0.62 & Agree \\
\hline $\begin{array}{l}\text { 7. I believe that infographics help me to connect new and old } \\
\text { information easily. }\end{array}$ & 3.32 & 0.56 & Agree \\
\hline 8. I think that infographics improve my critical thinking. & 3.68 & 0.48 & Strongly Agree \\
\hline $\begin{array}{l}\text { 9. I believe that infographics make it easier for me to recall } \\
\text { information. }\end{array}$ & 3.48 & 0.59 & Agree \\
\hline $\begin{array}{l}\text { 10. I think that infographics inform me about the responsible use of } \\
\text { images. }\end{array}$ & 3.36 & 0.57 & Agree \\
\hline Grand Weighted Mean & 3.40 & & Agree \\
\hline
\end{tabular}

Legend: 1.00-1.49 Strongly Disagree, 1.50-2.49 Disagree, 2.50-3.49 Agree, 3.50-4.00 Strongly Agree; WM= Weighted Mean; SD= Standard Deviation

As elucidated in Table 3, the respondents perceived that infographics improve their critical thinking skills with the highest weighted mean of 3.68 (SD 0.48) and can be verbally deduced as strongly agree. The findings positively confirm Fowler's (2015) results that infographics improved higher-order thinking skills which include critical thinking, analysis, synthesis, and advanced creative presentations. With the second-highest weighted mean of 3.64 (SD 0.49), the respondents strongly agree that infographics help them quickly understand complex information. The finding affirms that infographics can be considered an exceptionally functional tool to convey information that can be utilized to transfer complex or high amounts of data (Ozdamli, Kocakoyun, Sahin, \& Akdag, 2016).

Additionally, the respondents viewed infographics as a helpful tool to organize information into logical groups with a weighted mean of 3.60 (SD 0.50). In the last rank with a weighted mean of 3.08 (SD 0.64), the respondents agree on the idea that infographics help them filter out irrelevant data. The later may be improved among the respondents as it may maximize infographics' potentials in sorting data.

Generally, the respondents agree on the impacts of infographics on intellectual development; it received a grand weighted mean of 3.40. The findings coincide with Alrwele's study (2017) that infographics have significant education possibilities to improve learners' intellectual aspects.

\subsection{Perception of the Respondents on the Impacts of Infographics in Terms of Life Skills Development}

Table 4: Respondents'Perception of the Impacts of Infographics in Terms of Life Skills Development

\begin{tabular}{|l|c|c|c|}
\hline \multicolumn{1}{|c|}{ Life Skills } & WM & SD & $\begin{array}{c}\text { Verbal } \\
\text { Interpretation }\end{array}$ \\
\hline $\begin{array}{l}\text { 1. I feel that infographics help me to communicate what I have learned } \\
\text { to others. }\end{array}$ & 3.52 & 0.59 & Strongly Agree \\
\hline $\begin{array}{l}\text { 2. I believe that infographics motivate me to search the web for } \\
\text { appropriate images. }\end{array}$ & 2.80 & 0.50 & Agree \\
\hline 3. I feel that infographics improve my presentation skills. & 3.48 & 0.51 & Agree \\
\hline $\begin{array}{l}\text { 4. I believe that infographics teach me to choose and apply the } \\
\text { principles of design. }\end{array}$ & 3.44 & 0.58 & Agree \\
\hline 5. I feel that infographics help me acquire teamwork skills. & 3.48 & 0.51 & Agree \\
\hline Grand Weighted Mean & 3.34 & & Agree \\
\hline
\end{tabular}


Legend: 1.00-1.49 Strongly Disagree, 1.50-2.49 Disagree, 2.50-3.49 Agree, 3.50-4.00 Strongly Agree; WM= Weighted Mean; SD= Standard Deviation

Table 4 presents the respondents' perception of infographics' impacts in terms of life skills development. The first indicator received the highest weighted mean of 3.52 (SD 0.59), which can be interpreted verbally as strongly agree. It can be stated that the respondents were able to communicate to others what they have learned using infographics. Further, the respondents agree on the idea that infographics improve their presentation skills and acquire teamwork skills. It may suggest that infographics enhanced critical thinking and advanced creative presentations among learners (Fowler, 2015).

With the lowest weighted mean of 2.80 (SD 0.50), the respondents agreed that infographics motivate them to search the web for appropriate images. This infographics aspect implies a need to encourage learners to explore more on the related photos that may help them understand the lesson/concept being discussed.

On average, the respondents agreed on the life skills development impacts of infographics. It received a grand weighted mean of 3.34. Indeed, infographics helped learners communicate what they have learned, improved presentation skills, and acquired teamwork skills, among others.

\subsection{Perception of the Respondents on the Impacts of Infographics in Terms of Affective Development}

Table 5: Respondents'Perception of the Impacts of Infographics in Terms of Affective Development

\begin{tabular}{|c|c|c|c|}
\hline Affective & WM & SD & $\begin{array}{c}\text { Verbal } \\
\text { Interpretation }\end{array}$ \\
\hline $\begin{array}{l}\text { 1. I believe that infographics improve my ability to give and } \\
\text { receive feedback. }\end{array}$ & 3.52 & 0.51 & Strongly Agree \\
\hline Affective & WM & SD & $\begin{array}{c}\text { Verbal } \\
\text { Interpretation }\end{array}$ \\
\hline 2. I feel that infographics make me appreciate teamwork. & 3.40 & 0.50 & Agree \\
\hline 3. I think that infographics improve my motivation to learn. & 3.76 & 0.44 & Strongly Agree \\
\hline $\begin{array}{l}\text { 4. I think that infographics give me more self-confidence } \\
\text { regarding my ability to learn and succeed. }\end{array}$ & 3.28 & 0.68 & Agree \\
\hline Grand Weighted Mean & 3.49 & & Agree \\
\hline
\end{tabular}

Legend: 1.00-1.49 Strongly Disagree, 1.50-2.49 Disagree, 2.50-3.49 Agree, 3.50-4.00 Strongly Agree; WM= Weighted Mean; SD= Standard Deviation

As gleaned from Table 5, the respondents strongly agreed on the idea that infographics improve their motivation to learn and their ability to give and receive feedback, with computed weighted means of 3.76 (SD 0.44) and 3.52 (SD 0.51), respectively. The findings revealed that infographics encouraged learners to engage more in understanding lessons. It further improved their ability to collaborate with other learners. It can be claimed that infographics can be alternative instructional tools that may offer solutions among educators who teach abstract or multifaceted concepts that were complex to explain using orally presented material and written text.

In general, with a grand weighted mean of 3.49, the respondents agreed on the affective development impacts of infographics. It can be deduced from the results that learners improved their motivation to learn, give, and receive feedback, appreciated teamwork, and 
developed self-confidence when infographics are utilized in class. The findings agree on Alrwele's study (2017) that infographics have substantial education possibilities in developing the affective dimension among learners.

\subsection{Test of Significant Relationship Between Respondents' Perception of the Impacts of Infographics and Their Pre- and Post-test Performance}

Table 6: Test of Significant Relationship Between Respondents' Perception of the Impacts of Infographics and Their Pre- and Post-test Performance

\begin{tabular}{|c|c|c|c|c|}
\hline \multirow{2}{*}{ Perception of the Impacts of Infographics } & \multicolumn{4}{|c|}{ Respondents' Performance (Pre- and Post Test) } \\
\hline & $\begin{array}{l}\text { Correlation } \\
\text { Coefficient }\end{array}$ & $\begin{array}{l}\text { Qualitative } \\
\text { Description }\end{array}$ & $\begin{array}{c}\text { P- } \\
\text { Value }\end{array}$ & Remark \\
\hline Intellectual & 0.808 & $\begin{array}{c}\text { High } \\
\text { Relationship }\end{array}$ & 0.000 & Significant \\
\hline Life Skills & 0.685 & $\begin{array}{c}\text { Moderate } \\
\text { Relationship }\end{array}$ & 0.000 & Significant \\
\hline Affective & 0.611 & $\begin{array}{c}\text { Moderate } \\
\text { Relationship }\end{array}$ & 0.001 & Significant \\
\hline
\end{tabular}

Legend: \pm 1.00 Perfect Relationship, $\pm 0.91- \pm 0.99$ Very High Relationship, $\pm 0.71- \pm 0.90$ High Relationship, $\pm 0.41- \pm 0.70$ Moderate Relationship, $\pm 0.21- \pm 0.40$ Low Relationship, $\pm 0.01-+0.20$ Negligible Relationship, 0 No Relationship; Significant at $P<0.01$

Table 6 presents the test of the significant relationship between respondents' perception of the impacts of infographics and their pre- and post-test performance. Between "intellectual development" and the respondents' pre- and post-test performance, the computed correlation coefficient of 0.808 , with a qualitative description of a high relationship, is proven to be significant since its computed P-value of 0.000 is less than 0.05 level of significance. It is noteworthy to highlight a significant relationship between the respondents' perception of infographics' impacts as to "intellectual development" and their pre- and post-test performance.

The results implied that infographics significantly contributed to intellectual development among learners. It strengthened the study of Damyanov and Tsankov (2018), which elucidated that infographics create conditions for advancing various cognitive skills that encompass explanation, interpretation, evaluation, analysis, and conclusion. It is very significant since these encompassing skills promote higher-order thinking skills, which are necessary to encourage learners' academic achievement.

Regarding “life skills development"and the respondents' performance as to pre- and post-test results, the computed correlation coefficient of 0.685 , with a qualitative description of a moderate relationship, is proven to be significant since its computed P-value of 0.000 is less than 0.05 level of significance. Therefore, there is a meaningful relationship between respondents' perceptions of infographics' impacts on "life skills development" and the respondents' performance.

The findings suggested that infographics improve the cognitive domain and advance life skills development, such as communication and teamwork. These skills are essential in the $21^{\text {st }}$ - 
century learning environment to effectively relate and collaborate with others. Indeed, to communicate ideas and describe data to the broad community rather than the scientific community, infographics can be useful visual tools (Polman \& Gebre, 2015).

Between "affective development" and the respondents' performance as to pre- and post-test performance, the computed correlation coefficient of 0.611 , with a qualitative description of a moderate relationship, is proven to be significant since its computed P-value of 0.001 is less than 0.05 level of significance. It can be deduced from the result that there is a substantial relationship between the respondents' perception of the impacts of infographics on "affective development" and the respondents' performance. The results may indicate when infographics are utilized in class; it may promote motivation and self-confidence. Henceforth, infographics were ideal $21^{\text {st }}$-century tools that support and scaffold assessment of learning among educators and learners (Shively \& Maine, 2012).

\section{Paradigm on Infographics}

The paradigm on infographics based on the study results was developed to provide educators a tool to understand better infographics' potential in improving learners' academic performance.

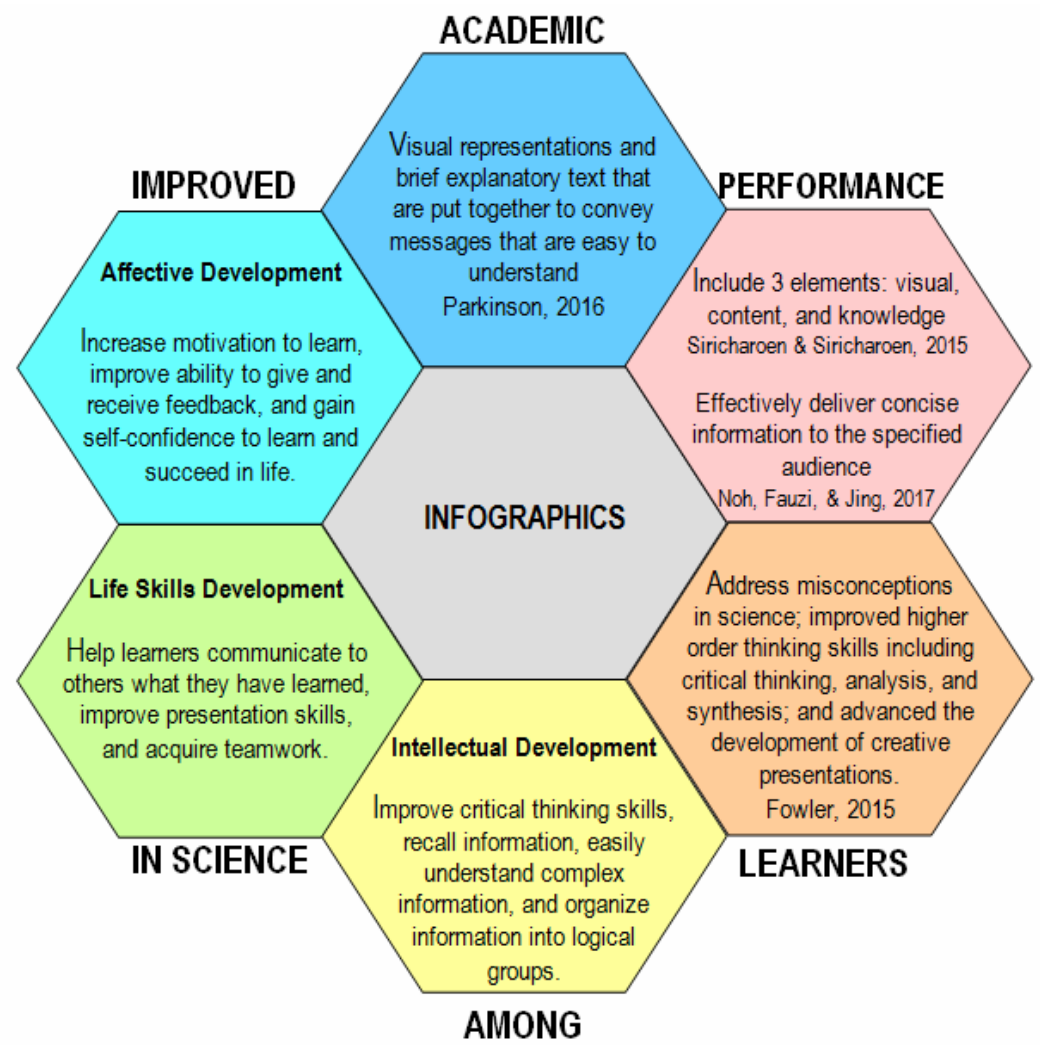




\section{Conclusion and Recommendations}

Based on the results of the study, the following conclusions were drawn: (1) the post-test results of the respondents improved statistically higher than their pre-test; (2) infographics were useful in terms of improving academic performance in Science among learners; (3) infographics, in terms of intellectual development, improve critical thinking skills, recall information, easily understand complex data, and organize information into logical groups; as to life skills development, infographics help learners communicate to others what they have learned, improve presentation skills, and acquire teamwork; and increase motivation to learn, improve the ability to give and receive feedback, and gain self-confidence to learn and succeed were the noted impacts of infographics in terms of affective development; and (5) the infographics paradigm was developed based on the results of the study.

Based on the findings of the study, the following conclusions were now advanced: (1) educators may use infographics in teaching science classes to improve academic performance among learners; (2) educators may utilize the paradigm to understand further the potentials of infographics in the teaching and learning process; and (3) future researchers may explore using infographics to different grade levels and another subject area/ course.

\section{References}

Alrwele, N. S. (2017). Effects of infographics on student achievement and students' perceptions of the impacts of infographics. Journal of Education and Human Development. Retrived from https://doi.org/10.15640/jehd.v6n3a12.

Damyanov, I. \& Tsankov, N. (2018). The role of infographics for the development of skills for cognitive modeling in education. International Journal of Emerging Technologies in Learning 13(1). Retrived from https://doi.org/10.3991/ijet.v13i01.7541.

Davidson, R. (2014). Using Infographics in the Science Classroom. (Online). The Science Teacher. Retrieved from https://www.semanticscholar.org/paper/Using-Infographics-inthe-Science-Classroom\%3A-Three-

Davidson/64641aa63a7272ad2bfefo9364f4d38c3e23bb2f

Department of Education. (2016). K to 12 science curriculum guide. Retrieved from www.deped.gov.ph.

Department of Education. (2019). PISA 2018 national report of the Philippines. Department of Education Complex, Meralco Avenue, Pasig City, Philippines.

Fowler, K. (2015). For the love of infographics. Science Scope 38(07). doi:10.2505/4/ss15_038_07_42

Gebre, E. H., \& Polman, J. L. (2016). Developing young adults' representational competence through infographic-based science news reporting. International Journal of Science Education, 1-21. https://doi.org/10.1080/09500693.2016.1258129

Naparin, H. \& Saad, A. (2017). Infographics in education: review on infographics design. The International Journal of Multimedia \& Its Applications (IJMA)9(4/5/6). doi: 10.5121/ijma.2017.9602

Noh, M., Fauzi, M., Jing, H. \& Ilias, M. (2017). Infographics: teaching and learning tool. Attarbawiy: Malaysian Online Journal of Education. 1 (1). Retrieved from https://scholar.google.com/citations?user=yjzUXrgAAAAJ\&hl=en\#d=gs_md_citad\&u=\%2 
Fcitations\%3Fview_op\%3Dview_citation\%26hl\%3Den\%26user\%3DyjzUXrgAAAAJ\%26citatio n_for_view\%3DyjzÜXrgAAAAJ\%3AULOm3_A8WrAC\%26tzom\%3D-480

Ozdamli, F., Kocakoyun, S., Sahin, T. \&Akdag, S. (2016). Statistical reasoning of impact of infographics on education. Elsevier B.V. https://doi.org/10.1016/j.procs.2016.09.414

Parkinson, M. (2016). Infographic tips and tools. Talent Development, 70 (5),p. 26-28. Retrieved fromhttps://billiondollargraphics.com/wpcontent/uploads/2016/05/MikeParkinson_Infog raphics_TD.pdf

Polman, J. L., \&Gebre, E. H.. (2015). Towards critical appraisal of infographics as scientific inscriptions. Journal of Research in Science Education, 52(6), 868-893. doi:10.1002/tea.21225

Rezaei, N.,\& Sayadian, S. (2015). The impact of Infographics on Iranian EFL learners' grammar learning. Journal of Applied Linguistics and Language Research, 2(1), 78-85.

Shively, C. H. \& Maine, L. (2012). Now i see! Visual and analytical routes to literacy through infographics. International Society for Technology in Education. Retrived form http://www.isteconference.org/2012/program/search_results_details.php?sessionid=700 38845 .

Siricharoen, W. V., \&Siricharoen, N. (2015). How infographic should be evaluated. In Proceedings of the 7th International Conference on Information Technology: 558-564. Retrived from https://doi.org/10.15849/icit.2015.0100

Tufte, E. R. (1990). Envisioning information. Cheshire, CT: Graphics Press.

Wertz, J., \& Saine, P. (2014). Using digital technology to complement close reading of complex texts. New Englandand Reading Association Journal, 50(1), 78-82, 85.

\section{Biographical notes:}

Dr. Raymart O. Basco completed his baccalaureate degree in Elementary Education Major in General Curiculum at the Batangas State University ARASOF- Nasugbu 2015, master's degree in Administration in Supervision at Dr. Francisco L. Calingasan Memorial Colleges Foundation Inc., 2017, and Doctor of Philosophy in Education Major in Educational Management at the Our Lady of Fatima University Valenzuela, 2020. Presently, he is an instructor at Batangas State University ARASOF Nasugbu. His research interests include pedagogy and innovation, and educational management. 